\title{
SECURITY ANALYSTS AS FRAME-MAKERS
}

\author{
Daniel Beunza \\ Department of Economics and Business, \\ Universitat Pompeu Fabra \\ daniel.beunza@upf.edu \\ and \\ Raghu Garud \\ Stern School of Business, \\ New York University \\ rgarud@stern.nyu.edu
}

January 5th, 2004 


\title{
SECURITY ANALYSTS AS FRAME-MAKERS
}

\section{Daniel Beunza and Raghu Garud}

\begin{abstract}
Security analysts offer a privileged entry point to study the construction of worth in markets characterized by Knightian uncertainty. Analysts have been portrayed as information-processors by neoclassic economists and as conformists by neoinstitutional sociologists. Neither perspective can explain the value that institutional investors report they derive from analysts' activities - access to industry knowledge and written reports - nor do they adequately address the difficulties associated with analyses in a situation of Knightian uncertainty, when new firm categories emerge. Departing from these perspectives, we conceive analysts as makers of calculative frames. Analysts calculate, but they do so within a framework. Similarly, analysts may appear to conform, but they also deviate from the pack to generate original perspectives on the value of a security, and, occasionally, displace prevailing frames. To explore the dynamics of creation, adoption and abandonment of calculative frames, we content-analyze the reports written by Henry Blodget on Amazon.com during the years of the Internet bubble, 1998-2001. We found that Blodget's reports offered a new calculative frame that allowed investors to analyze firms such as Amazon.com in a context of Knightian uncertainty when no stable information or shared predictions about Amazon.com's future existed. We explore the implications of our approach for an understanding of markets in general and analysis in particular during periods of Knightian uncertainty.
\end{abstract}

Word count: 11966

KEYWORDS: securities analysts, calculative frames, economic sociolgy

JEL Codes: L84, G24, G14 


\section{SECURITIES ANALYSTS AS FRAME-MAKERS}

\section{Daniel Beunza and Raghu Garud}

Despite the importance of security analysts to modern capital markets, there is hardly any consensus as to what they actually do or as to how they add value. One perspective on analysts is rooted in neoclassic economics. Adopting an under-socialized view, this perspective argues that analysts can identify the "true" value of a security by processing the latest available information (Savage, 1954). A contrasting perspective is rooted in the economics of information cascades and in the sociological processes of mimetic isomorphism (Bickchandani, Hirshleifer \& Welsh, 1992; Rao, Greve \& Davis, 2001). Adopting an over-socialized view, this perspective argues that analysts simply follow one another.

There is perhaps some validity to each of these perspectives. Analysts do calculate and they also look at each other as in a Keynesian beauty contest. But, if this is all that they do, then, it is not very clear what value fund managers find in analyst's reports. If analysts simply assemble data, as the neoclassic view suggests, what value do they offer their clients? Similarly, if analysts only follow each other, why would investment banks devote such staggering resources to cover companies?

An answer to these questions can be found in the annual polls and rankings elaborated by Institutional Investor, a portfolio managers' trade magazine. This magazine ranks analysts based on several different criterion according to the opinions of portfolio managers. What is interesting to note is that, amongst these criteria, stock selection was only the fifth most important factor and forecast accuracy was the sixth. The most important factor was an analyst's ability to provide fund managers with a roadmap. The tantalizing insight that this community appears to be suggesting is that analysts generate value, at least in part, by offering a framework for calculation.

That calculation presupposes a framework is not a new idea (cf. Allison, 1970; Bateson, 1972; Goffman, 1974). Indeed, for securities and industries that have stabilized, these frames become so taken for granted that they cede to the background (Berger \& Luckman, 1967). Such institutionalization occurs as metrics for evaluation stabilize, comparisons of securities along 
certain ratios become well accepted and there is an overall consensus as to industry dynamics. However, in situations where value is in the making, there is no solid ground on which to base one's calculations. For example, how were analysts of Internet compa nies to value firms that were losing money yet growing at unprecedented rates? What metrics, what P-E ratio and what parameters should they have used? It is under such situations of "Knightian" uncertainty (Knight, 1971) that original calculative frames make a difference. Under Knightian uncertainty there is no consensus as to the possible states of the world and no single way to calculate (Denzau \& North, 1994; Arthur, 1999; Callon, 1998).

Ours is not a unique idea. Any situation such as the emergence of echnologies or the promotion of an entrepreneurial venture, for instance, requires the creation of meanings and definitions with which corporate managers and venture capitalists can evaluate ill-working prototypes. These meanings and definitions are created through the use of metaphors, metrics and milestones that are contained in a new business plan. There is no reason why security analysts should be different from corporate managers or venture capitalists - after all, analysts too are located in contexts of Knightian uncertainty. Yet, the role of analysts as frame-makers has received remarkably little attention.

If analysts are indeed frame-makers, several key questions arise. How do they create a persuasive enough framework, and how do these frameworks operate? Under what circumstances do these frameworks stop functioning? To address these questions we followed the reports of one star analyst, Henry Blodget, and his journey as he covered one firm whose existence was surrounded with unprecedented controversy and debate - Amazon.com.

Our perspective offers several opportunities. For instance, it allows us to explain how new industry categories and markets emerge. Neither perspective on analysts -- as rational calculators or as followers -- can accomplish this task easily. For those who subscribe to analysts as rational calculators, any deviation is written off as being irrational (Shiller, 2000). For those who subscribe to information cascades or mimetic isomorphism, analysts pay a legitimacy price from non-conformance. A framework approach, in contrast, is able to suggest how and why analysts might be able to frame emerging situations as opportunities, and, in the process, generate status for themselves. 
Indeed, a framework approach introduces a more nuanced understanding of legitimacy. For those who subscribe to analysts as rational calculators, the symbolic act of engaging in calculation generates legitimacy (Feldman \& March, 1981). For those who subscribe to analysts as followers, social deviance extracts a legitimacy price (Aldrich \& Fiol, 1994). The frameworks approach considers an additional price - from "inter-temporal" inconsistencies (Frank, 1988). Specifically, abandoning a frame that has yet some time built into it midway generates illegitimacy. So, analysts cannot easily abandon their frames to follow others. At the same time, they cannot simply abandon their frame in light of contrarian data. They have to work with their frames as these frames are as much devices to make sense of what is happening as they are devices to see what might happen.

It is not surprising, therefore, that any framework will be challenged at some point in time. Indeed, there is every possibility that different stakeholders will evaluate emergent data in different ways depending upon their own interests and mental models. In other words, the same data can be understood in different ways, and this generates controversy, especially under conditions of Knightian uncertainty. In sum, our framework approach allows us to endogenize the genesis of controversies besides the genesis of novelty.

\section{PERSPECTIVES ON ANALYSTS}

Existing treatments of securities analysts are structured around two theoretically disparate strands of literature. The neoclassic economic approach views analysts as information processors. From this perspective, analysts are expected to perform no worse than the market. But according to economic studies of analysts, they actually perform worse. In contrast, the sociological literature portrays analysts as imitators. From this perspective, analysts provide some value by herding as judges may do in a Keynesian beauty contest. But critics of this perspective maintain that analysts herd at their own risk and exhibit post-decision regret.

We depart from the bleak conclusions of the existing literature by noting that beneath the critical views of analysts noted above, there are sharp differences in assumptions about the nature of analysis, the core activity performed by analysts. Whereas the economic literature presents an under-socialized view that reduces analysis to information gathering, the sociological approach rejects analysis altogether, positing instead an over-socialized portrait of analysts 
imitating each other. Since these two approaches are theoretically inconsistent, their implications cannot simply be taken to reinforce each other. Furthermore, both approaches fail to present an account of analysis under Knightian uncertainty.

\section{Securities analysts and calculative choice}

The approach to analysts as information processors is predicated on the model of rational decision-making under risk developed by Savage (1954). According to Savage's model, investors' decisions to buy and sell follow their subjective probability estimates about future price and earnings, that is, their beliefs. Actors incorporate new economic news into their prior beliefs through a mechanism of "updating" that we can think of as Bayesian calculation. Rational investors will update their beliefs in the same direction, becoming more optimistic about a company's stock price with the arrival of good news, and vice-versa. The same piece of news, in other words, will never lead investors to update their beliefs in opposite directions. Thus, even if investors start from different beliefs about the future, they will eventually converge - i.e. a path independent process. As a result, an information-processing view of calculation predicts consensus in beliefs - and a consensus that is "correct." Calculating future prices and earnings is thus a straightforward, even simple task.

This information processing view of calculation underlies the efficient-market hypothesis of neoclassic finance. If information is available to investors and their beliefs converge, stock prices will instantly incorporate all relevant information about the value of companies. Some investors will "overshoot" their estimates, others will "undershoot" them, but, on average, these errors will cancel out. Markets will be informationally efficient, and there will be no mispriced stocks and no investment opportunities (Samuelson, 1965; Fama, 1969).

Similarly, an information processing view of calculation underlies economic studies of analysts. The function of analysts from such a consideration is to search and assemble information. The best analysts can do is to ensure that, on the average, their predictions are no worse off than a random forecast. But economists are reluctant to accord analysts even this limited role. Starting with Cowles' (1933) seminal piece, "Can Stockmarket Forecasters Forecast?" economists have benchmarked the performance of analysts against a variety of quantitative measures and found it to be surprisingly lacking. Cowles (1933) and a long 
succession of authors found that the stocks recommended by analysts produced returns below those of a random portfolio (McNichols \& O'Brien 1997; Bidwell 1977; Logue \& Tuttle 1973; Diefenback 1972, Cowles 1933). A related line of inquiry examined the accuracy of analysts' earnings forecasts, and found these to be systematically biased upwards (Degeorge, Patel \& Zeckhauser, 1999; Lim 2000). In sum, the existing economic literature presents analysts as inaccurate forecasters and unprofitable investment advisors.

In this paper, however, we focus on the performance of analysts in a radically different context, the years of dramatic financial volatility between 1998 and 2001. The trading patterns of investors during this time were famously characterized as irrational exuberance (Shiller, 2000). Such was the magnitude of the bubble experienced by the American stock market that it has prompted a re-examination of the process whereby analysts incorporate information into prices.

We see the years 1998-2001 as a period of Knightian uncertainty in which actors did not know possible future contingencies and their probabilities. Under these conditions, Savage's model is clearly inapplicable. If decision-makers ignore which probability distribution applies and use different ones as a result, additional information will not produce convergence in their beliefs. Those who fail to consider a contingency as possible (formally, a "zero-probability" event) will also ignore incoming information about it, and as a result not update their beliefs (Brandenburger, 2002). For instance, in the case of Amazon, some analysts valued the firm in terms of how many books it could sell while others considered the contingency that the firm might diversify and sell a wide range of products.

Another limitation of the information-processing model under conditions of uncertainty is that it overlooks the effects of differences in the meanings that decision-makers give to information. The meanings accorded to a given piece of news determine the way in which a decision-maker will combine it with prior beliefs to shape her posterior ones. In Savage's model, news means the same to every decision-maker. In contrast, under conditions of Knightian uncertainty, different actors may attribute different meanings to the same piece of news - i.e. a path dependent process (David, 1985). As a result, the arrival of additional information will not bring posterior beliefs any closer and thus fail to produce convergent opinions. 
The limits to simple calculation in contexts of Knightian uncertainty call for important changes in our theoretical approach to how decision-makers behave. Prominent economists such as Denzau and North (1994) have cogently articulated this need. They suggested, "if problem complexity is too great, then the substantive rationality results do not hold" (1994:12). "Modeling such situations," the authors follow, "require one to model the decision maker as building internal mental models to represent the world and to learn from that world in order to improve the resulting choices" (Denzau \& North, 1994:12).

In a related line of inquiry, game theorists seem to have heeded the suggestion of Denzau and North (1994) and have taken up the study of how decision makers build their own mental models under uncertainty. Differences in beliefs across players had traditionally been considered irrelevant to the outcome of strategic interactions. Game theorists had instead assumed identical beliefs (so-called "common knowledge") on the part of the actors involved. But a novel and prominent body of literature known as "epistemic game theory" centers on the problem of how actors build and improve their models of the world (Brandenburger, 2002).

Radner (1997) expressed the predicament of individuals in these contexts when he asked -- What does it mean to be rational in a context where the definition of rationality itself is being contested? One answer can be found in literature on institutional sociology. An insight that this literature has to offer is that individual decisions are often determined by group norms and values rather than by individual self-interest. We turn to these non-calculative models of choice below.

\section{Securities analysts and non-calculative choice}

A recent body of neo-institutional literature on securities analysts portrays calculation as nearly impossible and analysts as imitators. According to Zuckerman and his colleague (Zuckerman, 1999; Zuckerman, 2001; Phillips \& Zuckerman, 2001), analysts, at best, engage in 'weak calculation', a process that leads to conformity amongst analysts amongst the companies that they cover. Furthermore, Rao, Greve and Davies (2001) are even more skeptical about the ability of analysts to calculate and argue that analysts eschew calculation in favor of imitating their peers.

Zuckerman and his colleague present security analysts as crucial actors whose work is nevertheless beset by calculative limitations. According to Zuckerman (1999), analysts play an 
important intermediary function in the market. They are critics, whose job it is to help consumers assess value when it is uncertain, as in the case of high-end restaurants, modern art or equity investments. However, Zuckerman argues, under uncertainty, value can only be assessed by comparison, and these comparisons can only be performed among sufficiently similar candidates, like those belonging to the same category. Consequently, analysts screen out those companies that do not belong to any existing category. This generates an "illegitimacy discount" for those firms that, like conglomerates, straddle several categories. An implication is that, by discounting the new and unfamiliar, analysts stifle technological change and organizational innovation.

Phillips and Zuckerman (2001) note that analysts themselves are evaluated by Institutional Investor magazine and the companies that they cover. The latter attempt to avoid negative reviews on the part of analysts by withholding additional information from those who issue "sell" recommendations. This places pressure on the analysts to restrict their recommendations to positive or neutral advice, with the unwelcome effect that less than five percent of all analysts' recommendations are advice to "sell." According to the authors, however, not all analysts are similarly affected: middle-status analysts, with their insecure standing in the profession, are most threatene $\mathrm{d}$ by the retaliation of companies

Whereas Zuckerman and his colleagues argue for a theory of 'weak calculation', Rao, Greve and Davis (2002) propose a mimetic theory of analysts. The authors examine a recurring dilemma for securities analysts: whether to cover a new listed company or not. Clearly, the decision cannot follow an exhaustive and complete evaluation of a company's value, for that would require that analysts cover the company in the first place. Instead, the authors argue that analysts resort to imitating the coverage decisions of their peers, especially the high-status ones.

However, imitation can produces dysfunctional information cascades (Bikhandani et al, 1992). Cascades are strings of identical and potentially 'erroneous' recommendations. They arise when several agents face an uncertain decision in sequential order and seek to reinforce their own limited judgment by looking at the decisions of others. If many of the initial decisionmakers opt for the same alternative, subsequent actors will take those choices as strong evidence in one direction, disregard their own judgments and follow the crowd. As a result, if the initial 
decisions happen to be mistaken the entire crowd of followers will end up choosing the wrong course of action.

The negative consequences of imitation go beyond coverage decisions, reducing the accuracy of analyst recommendations. According to Rao et al. (2001), analysts only initiate coverage when they are optimistic about the value of a stock. As a result, only optimistic cascades ensue. Thus, the authors found that "analysts that adopted in the wake of an information cascade were more likely to be overly optimistic about the firm's earnings prospects" (Rao et al., 2001: 521; emphasis added). Indeed, the same analysts that initiated coverage as part of a cascade were, according to the authors, more likely than others to "become disappointed and subsequently to abandon coverage" (Rao et al., 2001: 521). Thus, analysts come across as beset by severe cognitive limitations. They are "cognitive misers" (Rao et al., 2001: 521), too limited in their cognitive ability to engage in systematic information processing, but smart enough to regret the negative consequences of their herding.

The sociological literature on analysts offers a focus that contrasts and complements the economic focus on information processing in several ways. First, by treating analysts as critics, the work of Zuckerman gives analysts the substantial intermediary role that neoclassic theories deny. The study of analysts, their social relations and professional concerns brings social structure back in our understanding of seemingly disembedded mass markets such as capital markets (Hirsch, 1975; White 1993; Podolny 1993). Another strength of Zuckerman's theory of weak calculation is that it addresses the calculative difficulties that Knightian uncertain creates. An important strength in the work of Rao et al. (2001) is that it widens the repertoire of analysts' strategies by introducing imitation, a resourceful alternative to calculation in contexts of uncertainty.

However, these perspectives of analysts fail to address the core of the analytical activity performed by analysts. The model of weak calculation and conformity developed by Zuckerman and his associate does not account for the emergence of new categories, thus raising the question of how a new category such as the "Internet Company" emerges. In addition, Zuckerman highlights the status of analysts as a key variable, but in the process, does not explore how star analysts gain their high status. 
Similarly, Rao et al.'s work overlooks the function of information processing among analysts. First, it presents imitation as a cognitive shortcut to information processing. Whereas we agree with the authors that imitation is best suited for low-stakes decisions such as "how fast to drive on a certain stretch of highway, or how to each chicken in a restaurant" (Rao et al., 2002:504), we also believe that these shortcuts hardly seem fit for the high-stakes nature of analysts' work. Second, the cascades model ignores analysts' calculations in the form of reports: the model assumes that decision-makers can only see the decisions of their predecessors, but not their rationale -- and yet, analysts have at their disposal the full text of the reports written by their predecessors. Indeed, securities reports have the distinct appearance of measurement instruments, not imitation tools. Reports are replete with tables, formulas and references to metrics. Why would analysts write in this way? An answer to this question is that they offer fund managers with a framework with which they can calculate.

\section{A frame -making approach to securities analysts}

In developing our perspective on analysts as frame makers, we turn once again to the criteria by fund managers to rank analysts. According to the Institutional Investor poll, the attributes that portfolio managers find most desirable in an analyst are industry knowledge and written reports (see Table 1). In other words, analysts generate value not just by providing recommendations about whether to hold or accumulate a particular stock, but also by providing fund managers with a consistent way to profile a firm and the industry to which it belongs.

$$
\text { -- Table } 1 \text { here -- }
$$

Building on these observations, we propose that security analysts help investors by developing frames that enable them to analyze securities in contexts of Knightian uncertainty. We see analysts as frame-makers. Indeed, analysts' work becomes critical under Knightian uncertainty, when no accepted interpretation or shared prediction about the future exists. In such contexts, future contingencies and their probabilities are unknown and conflicting interpretations of the same information coexist, making it impossible for investors to engage in simple information processing. Analysts help investors by providing a cognitive guide and accompanying measuring apparatus that allows them to attach a magnitude of worth to securities. 
Indeed, Knight himself suggested that uncertainty calls for market actors to use frameworks, or, in his own words, "image[s] of a future state of affairs."

Our perspective bridges several theoretical streams. The need for a frame reflects a core argument in the literature on cognitive psychology (Kelley, 1963) and cognition in organizations (Weick, 1979), according to which market actors have a basic need for mental maps of their competitive environment (Huff, 1990; Porac et al, 1995; Lant \& Baum. 1995). A map or frame helps categorize a firm and places it within a hrger industry context including its competitors, collaborators, potential entrants and its customers. Indeed, some authors have gone further, and argued that mental models are not just important, but the essence of organizing (Weick 1979).

Calculative frames lie at the center of modern economic sociology. Our approach is part of a stream of literature in economic sociology that aims at advancing past the notion of embeddedness and non-calculative exchange. One fruitful approach to further this agenda is to examine the social and institutional determinants of calculative market activities (Callon 1998, Podolny 1993, Stark 2000). According to Callon, "calculating (...) is a complex collective practice which involves far more than the capacities granted to agents by certain economists," especially in contexts of Knightian uncertainty (Callon 1998:4). What, asks Callon, allows calculation to emerge? Different studies have addressed this question by examining how a variety of organizations and technological tools facilitate calculation. Some of these include supermarkets, securities exchanges or financial trading rooms (see respectively Cochoy 1998; MacKenzie \& Millo 2003; Knorr Cetina \& Bruegger 2002; Beunza \& Stark 2004). Our work on securities analysts lies in the same tradition.

The notion of analysts as frame-makers also draws from the literature on innovation and entrepreneurship. This body of literature provides us with an appreciation of how technology practitioners themselves grapple with the challenge of establishing grounds for rational decisionmaking (Weick, 1979; Garud \& Rappa, 1994). According to this literature, during periods of creative destruction (Schumpeter, [1942] 1975), the evaluation of new technologies proves extremely difficult, as new technologies often appear to be initially ill-formed and worthless. Moreover, multiple trajectories emerge, each with its own dimension of merits (Dosi, 1982; 
Tushman \& Anderson, 1986) and it is not clear ex-ante which specific technological trajectory will prevail.

Innovation and entrepreneurship researcher found that innovators coped with evaluation under uncertainty by using framework-like logics. Innovators provide investors with templates for evaluating their progress over time. These include "milestones" -- identifiable achievements that the firm defines as progress and which set expectations against which progress can be measured. Since performance cannot be measured until prototypes are working, investors rely on alternative new metrics. Thus, in the case of technology and innovation, a preliminary stage of framing precedes the incorporation of data into assessments of progress and value: companies make meaning by defining ex-ante the ways in which results should be interpreted. We propose that security analysts perform a similar role.

Frames are also at the center of other important literature streams that are nevertheless related to the case of securities analysts (see Dunbar, Garud \& Raghuram 1996). The sociological literature on symbolic interactionism proposed "frame analysis" to examine the socially-determined principles that organize actors' experiences of events (Goffman 1974). And, although described in a different language, the philosophy and sociology of science has consistently emphasized the presence of incommensurate clusters of associations that can give the same data different meaning (Kuhn, 1962; Gallison, 1997). Even in economics, a recent body of research known as "cognitive economics" seeks to replace the black box of neoclassical rationality (Arthur, 1988) by examining "the way in which humans develop mental models to structure their environment" (North \& Denzau, 1994:4).

One key theoretical advantage of our frame-making perspective is its ability to reconcile analysis with Knightian uncertainty. We see investors as engaging in information processing, but with the use of a calculative frame. Within a given frame, calculation resembles the information processing activity described in the neoclassical literature - it is a matter of searching and assembling data. But investors also face the problem of constructing the frame, or borrowing elements of others' frames. Analysts provide frames. Their work consists of creating new frames and persuading investors that theirs are better than the competitors'. 
Our perspective raises several questions. What are the constitutive elements of a frame, for instance? How do they work? And, when are these frames abandoned? In the rest of the paper, we will explore Henry Blodget and Amazon.com to address these questions.

\section{RESEARCH SITE AND METHODS}

Our study inquires into the activities of security analysts with a qualitative content analysis of the reports written by Henry Blodget and selected other analysts on Amazon.com. By analyzing Blodget's reports at different points in time, we hope to understand how he constructed a novel calculative frame, how this frame operated, and how it eventually was discredited. Our approach follows a long tradition of content analysis in organization theory (e.g., Barley et al. 1988) and science studies (Latour, 1987).

Why focus on Amazon? We want to study a context of Knightian uncertainty, and we believe that the company captures like no other the dynamics of emergence and analysis during the Internet boom period of late 1990s. A child of the Internet revolution, Amazon also was an unfolding organizational experiment. As one would expect of such experiments, multiple and often conflicting assessments of the company coexisted at any point in time: would dot-com firms replace retailers, travel companies and eventually the entire American economy? Could they be worth more than the entire "Old Economy" combined? Or were they a fad that would disappear?

Why study Henry Blodget? Blodget was, according to Institutional Investor magazine, the leading Amazon analyst at the time (Table 2). The Street.com ranked him the top most analyst in 2000 for his ability to make fund managers think - ranked at 3 stars, the highest possible level - (even though Blodget was ranked number 15 on his ability to pick stocks). Between 1998 and 2001 Henry Blodget covered Internet stocks such as Amazon, eBay or America Online. He made headlines on the Wall Street Journal and The New York Times. He was even credited with the ability to "move markets." Following some of his reports can provide a sense of how and why analyses proceeded during periods of Knightian uncertainty.

$$
\text { -- Table } 2 \text { here -- }
$$

To conduct our content analysis, we relied on a variety of sources. We downloaded analysts' reports from Investext, an academic database that provides full-text PDF files of the 
reports. Two of us carefully examined them in chronological order, making marginal notes. We then built a database with the key variables used from the reports such as price targets, recommendations, key metrics, etc. This allowed us to locate specific instances of controversy. We contrasted Blodget's views with the positions adopted by other analysts in top investment banks (Goldman Sachs, Deutsche Bank, etc.) by using Ratingplotter charts, an analytical tool developed by Investars, an analyst-rating company.

From this wealth of information, we only present three critical episodes in a three-year long saga. They all revolve around controversies. As Nelkin (1979) has suggested in the context of technology policy, studying such controversies provides us with an unique vantage point to understand how something comes about before it becomes a black box and becomes taken for granted. Similarly, focusing on these three episodes provides us with an unique perspective into the nature of the exchanges during the period of creative destruction. Indeed, we carefully chose these episodes to highlight the value of looking at analysts as frame markers and to see how such a perspective advances our understanding of markets and analyses during periods of Knightian uncertainty.

\section{HENRY BLODGET'S COVERAGE OF AMAZON.COM}

In 1994, Jeff Bezos, then a 29-year old Wall Street investment banker, decided to start up a company to benefit from the Internet boom. Bezos concluded that books were the ideal product to sell online. A virtual bookstore could store far more books in print than a physical shop. Consumers would have less need for the "touch and feel" of a book than for a piece of cloth or food, Bezos reasoned. And the largest book retailers at the time, Barnes and Nobles and Borders, only controlled $12 \%$ of the market. Thus was born Amazon.com. It opened for business on the Web in July 1995, having first raised private capital. By the end of 1996, the company was on a course of escalating revenues and losses that would end up characterizing it.

\section{First episode: Igniting the dot-com boom}

The first of the three controversial episodes on Amazon began at end of the summer of 1998 (see Figure 1). At the time, Amazon had attracted considerable attention from security analysts. Its main detractor was Jonathan Cohen, first vice-president at Merrill Lynch. Cohen 
categorized Amazon as a bookstore, and dismissed Amazon's high stock price by counting how many books it would have to sell to justify its valuation. He wrote,

Bookselling is an inherently competitive and low-margin business. Because the intellectual property value contained in published works typically represents only a small portion of the price to end-users, we do not expect that moving that business to an online environment will meaningfully change those characteristics (Cohen 1998:1).

Thus, to the extent that Amazon was a bookstore, its growth potential was bound by the (limited) ability of any book retailer to grow its book sales.

In this context, Blodget's first report made a splash. In October 1998 Blodget issued a report on Amazon titled “Amazon.com: Initiating with Buy.” In this long, 31-page single-spaced document, Blodget conducted an exhaustive strategic analysis of Amazon of extraordinary flow and eloquence in which he laid out his differences from the prevailing approach at valuing Amazon, as personified by Cohen.

Blodget's report was divided into three parts. In the first, Blodget analyzed the competitive threat posed to Amazon by Barnesandnobles.com, the e-commerce subsidiary of the giant bookstore chain. "Would competition squash it?" In the second, Blodget considered the future profitability of Amazon: "Will it ever make money?" And in the third he considered valuation: Was this money-losing company outrageously over-valued at $\$ 91$ ?

Amazon's profitability Blodget considered the future profitability of Amazon in the second section of his report. Doing so presented a difficult challenge: the discounted cash flow models typically used by analysts used current profits as a proxy for future profits, but Amazon suffered losses at the time. As a result, a traditional valuation would show a negative value for the company.

Blodget overcame this paradox by rejecting current profits as a proper proxy and turning instead to some other metric. He engaged in a creative exercise of association and asked, what Amazon was like? Was it like a book distributor with razor-thin margins around 0 percent? Was it like bricks and mortar book retailers with a future net margin of 1-2 percent? Was it like other direct-sales companies such as Dell with fatter margins of 8 percent? Or was it like "pure-play" 
Internet companies like eBay with even fatter margins of 15 percent? Clearly, the answer was critical for calculating the value of the company.

Blodget's reply was that Amazon should not be valued as a bookstore. "We don't view Amazon.com as a book retailer," he wrote. Instead, Blodget proposed an entirely new industry category, "the Internet company." He described Amazon as follows:

We see it as an electronic customer-services company in the business of helping its customers figure out what they want to buy (...) and then delivering it to them at a good price with minimum hassle (p. 1). We value AMZN the same way we value other Internet stocks. (Blodget 1998d:20)

Blodget thus freed himself from conventional conventions and constrains in valuing Amazon: he could assume for the company the breakneck growth rate of a start-up. Indeed, Blodget argued that Amazon was like Dell Computers.

The association of Amazon to Dell illustrates a larger point about calculative frames. The selection of relevant metrics to value a company is contingent on the answer to the question: "What is this a case of?" A book retailer can be valued in terms of its potential for selling books. A diversified retailer cannot. Thus, we see that categorization of the company at hand is a important building block of a calculative frame. The choice of category helps build a network of associations and dissociations that any analyst establishes (Bowker \& Star, 1999; Callon, 2002; Lounsbury \& Rao, 2004; Zuckerman, 1999).

Table 3 provides a summary of the assumptions used by Blodget in comparison to those used by Cohen to evaluate. Amazon.com. Several facets stand out. First, both assessments have an internal consistency to them. Second, the contrasts are remarkably apparent. Third, the two analysts appeared to be tapping into two different kinds of fund managers. Whereas Blodget used his analysis to address risk seeking fund managers, Cohen used his frame to address the risk averse.

\section{-- Table 3 about here --}

Valuing Amazon In the third section of his initial report, Blodget considered what the total value of Amazon should be. By associating Amazon to Dell and making a few more assumptions about sales, Blodget arrived at a value of $\$ 50$ a share. This was disappointing, if we consider that with the stock trading at \$91 it hardly made for a "buy" recommendation. Aware of 
the lackluster excitement of a $\$ 50$ price target, Blodget tagged on to the "official" analysis a second, much more optimistic one. He wrote, "let's tweak [the] assumptions a bit and see what happens,"

Let us assume that the company manages to grow its active customer base a bit faster than $30 \%$ per year (...) The active customer base would increase from an estimated 1.7 million today to 16 million in 2003. And let's say that instead of making 1.5 purchases a quarter, customers become more seduced by the joys of shopping online and up their purchases to 2.5. Then let's say that... Amazon.com has lots more cool stuff on sale than it does now so that each time customers buys something [sic], they make an average purchase of $\$ 60 \ldots$ Place a $12 \%$ operating margin on this revenue estimate... and suddenly the stock is worth $\$ 350$ (Blodget and Erdman, 1998: 21; emphasis added).

Blodget was thus enlarging the network of associations to emphasize the excitement of buying on-line, the trendy or "cool" character of Amazon at the time, and to an operating margin above Dell, closer to Yahoo or eBay. This illustrates an additional use of frames first identified by Allison (1971). Frames explain and also guide selective associations. According to Allison (1971:4) "conceptual models not only fix the mesh of the nets that the analyst drags through the material in order to explain a particular action; they also direct him to cast his nets in select ponds, at certain depths, in order to catch the fish he is after." Blodget was a master fisher.

Blodget had so far made the case for a valuation of Amazon at $\$ 50$ and at $\$ 350$. Which one was right? Blodget argued that a clear-cut valuation was impossible. He wrote,

With AMZN we can twist a few dials and knobs and conclude that the stock is worth anywhere from $\$ 1$ to $\$ 350$. So rather than declare definitely what we think is worth - a ludicrous assertion, in our opinion - we will explain why we think there is compelling long-term upside to the current valuation (Blodget and Erdmann 1998: 20).

In sum, given the state of uncertainty about the future of the company, Blodget argued that precise calculation was impossible, as it was too dependent on the assumptions. Thus, he wrote: "change the assumptions, do the multiplications and - voila!" a different value comes out (Blodget and Erdmann, 1998: 20). This is precisely the problem that investors face under Knightian uncertainty.

Blodget's refusal to offer a point estimate for Amazon's value provides additional lessons. If not with his valuation, how did Blodget help his readers, the portfolio managers? 
Blodget was writing for speculators. Speculation, an expression with its origins in the Latin word speculare or "to regard," requires looking at assets in different ways and accepting, almost playfully, that there is no single right way to do so.

Faced with the impossibility to calculate, Blodget avoided analysis-paralysis by taking a sudden turn to judgment, sentiment and attachment. He wrote:

We conclude, therefore, that AMZN is worth somewhere between $\$ 1$ (..) and $\$ 350$ (...) with the real value probably close to $\$ 75$. We love the opportunity, the company, the management, and the potential upside, so we are recommending the stock heartily for the long-term investors who don't mind volatility (Blodget 1998d: 20, emphasis adde d).

The choice of words is telling: "love the opportunity," and "recommending (...) heartily." Blodget's frame was built with a judgment-based, affective, entrepreneurial move.

Blodget justified his recommendation further by mobilizing time as a resource. For instance, his overall summary read "We are recommending the stock for strong-stomached, longterm investors." Like any good entrepreneur buying time from a venture capitalist, Blodget wrote “We expect the company's accumulated deficit to balloon to more than $\$ 300$ million before it finally starts reporting profits in the spring of 2001." Moreover, he also offered an overall time frame when Amazon.com would become profitable. Blodget wrote "[We] concluded that amazon.com could be a $\$ 10$ billion business with a $12 \%$ operating margin in five years.

In sum, Blodget managed to mobilize anywhere from two and a half to five years for Amazon.com and for his analysis, and, in doing so was able to draw investors' interests. It may not be accurate to value Amazon above \$91, Blodget admitted to investors, but you will only profit if you do so. He wrote,

Our analysis ... conclude[s], not surprisingly, that, relative to conservative performance forecasts, the stock is shockingly expensive ... In the short history of the Internet industry, however, the big money has been made by investors who had the faith to invest in the stocks of the best companies before their business models were proven (Blodget 1998d: 4)

Blodget thus gave the reader a clear choice - be precise or be rich. At this point, the reader is reminded of who he or she is: not a technologist, not a dispassionate observer, but an investor who is paying for the reports to find investment opportunities. And here was someone speaking investor language. Investors eventually came around to Blodget's view. 
The December report The report outlined so far set out Blodget's frame for Amazon. But the analyst reached his stature as leading Internet analysts in a subsequent piece issued three months later. Following Blodget's report in October, Amazon had an exceptional Thanksgiving performance in sales. Investors bid up its price to $\$ 270$, making the price targets of $\$ 100$ and $\$ 150$ issued by analysts look more and more outdated.

On December $16^{\text {th }} 1998$, however, Blodget bluntly raised his price target from $\$ 150$ to $\$ 400$ (Blodget and Anning, 1998). The price target made headlines in the financial press, not the least because the company was valued at $\$ 50$ by Merrill Lynch's Cohen. On that same day, within hours of Blodget's report, the price of Amazon rose by a stunning twenty percent. Cohen counter-attacked at mid-day by issuing a press note in which he emphasized that Amazon was not worth more than $\$ 50$. But the note did not depress the price. Weeks later, the price of Amazon surpassed Blodget's price target and the analyst topped the Institutional Investor rankings and eventually replaced Cohen as head Internet analyst at Merrill Lynch.

Consider the picture of analysts that emerges from this episode: Conformists? No. Calculators? No. Instead, we see how different securities analysts using the same information (but different calculative frames) produced disparate price targets and recommendations: Cohen valued Amazon at $\$ 50$, while Blodget did so at $\$ 400$. Both had developed frameworks or, in Allison's (1970: 4) words, "models in terms of which analysts and ordinary laymen ask and answer the questions: What happened? Why did it happen? What will happen?"

\section{Second episode: Defending Amazon's against Barron's}

The second crucial episode in the controversy over Amazon's value took place in summer of 1999, during a period when extreme optimism about the Internet prevailed. Consumers were making Christmas purchases on the Web, Internet companies were rushing off to their initial public offerings, and the NASDAQ was continuing with its steep climb. On May 1999, however, the prestigious financial newspaper Barron's proclaimed Amazon to be grossly overvalued. Blodget's response illustrates a brilliant rhetorical device, re-interpretation, and the social dynamics of competition for status that takes place among analysts.

To understand re-interpretation and Blodget's defense of Amazon, let us first examine Barron's attack. Barron's journalist Alan Abelson based his offensive on some recent sales of 
the stock. Margins in book retailing, Abelson claimed, were low, "with two leading outfits in the field bringing down to net only two to three pennies of every sales dollar." Amazon's model of virtual bookstore did not help matters, for "no less than 25 cents of every dollar Amazon takes in rather quickly goes out for marketing and sales." Thus was dismissed Blodget's carefully crafted theory of Amazon's "virtual shop front" that required no rent.

Abelson continued by questioning the claim that Amazon was more than a book retailer. Amazon had expanded into CDs, Abelson granted, but "the only thing [it had] proved so far is that it can lose money selling books and lose still more money selling CDs." The criticism was much more devastating than it seems, for it undermined the core of Blodget's categorization of Amazon as something that was not a retailer but an Internet company. Abelson valued Amazon as a book retailer: "Barnes \& Noble's stock sells for a tad over 80 percent of revenues. Amazon's stock sells for a tad over 33 times revenues. Something's out of whack" (Abelson, 1999: 5) Abelson proposed a total value for Amazon of a paltry one seventh of the company's market value at the time.

Abelson's arguments spread around Wall Street like wildfire. The stock price of Amazon was under threat. If Blodget wanted to remain the leading Internet opinion-maker, he had to defend his emblematic stock. In a stunning piece of persuasion titled "Amazon.Bomb? Negative Barron's Article," Blodget addressed each and every concern raised by Abelson about Amazon. But, instead of rejecting the issues raised by Abelson in the Barron's article, Blodget acknowledged them and then turned them into reasons for investing in Amazon.

How does one translate bad news into good, iron into gold? Consider, for example, Blodget's treatment of Amazon's lack of profitability. As noted above, Abelson had forcefully suggested that a company without profits such as Amazon could not be too valuable. In reply to Abelson complains, Blodget wrote,

As any smart investor understands, there is a big difference between 'losing' money and 'investing' money. Amazon.com is investing money, not losing it, so near-term profitability is not a good measure of future worth. Put another way, if Amazon.com were to cut back on its investments in order to post a near-term profit, we believe it would be worth considerably less in three to five years than it will be if its current investments pay off. (Blodget and Anning 1999: 6). 
Blodget thus performed a judo-like maneuver that reinterpreted his opponent's information in a way that not just altered but actually reversed its implications for the valuation of the stock. To do so, Blodget evoked time as a resource to argue how and why a potential concern about Amazon's lack of profit was in fact a signal to the smart investor about the future value of Amazon's stock. Specifically, by evoking time as a resource, Blodget was able to severe the conventional association between stock price and profits, and established instead one between price and losses. Sheltered in the calculative frame that he had built, information on losses could do him no harm.

The practice of re-interpretation has important implications for our model of security analysts. From an information-processing perspective, analysts are Bayesian decision-makers that use new information to update their probability assessments in the same direction. From an information cascades perspective, under conditions of ambiguity that is an integral part of a controversy, analysts may simply succumb and follow the others. Blodget did neither. The reinterpretation that Blodget accomplished incorporated new information in a direction that was opposite to the one that other analysts had.

To be sure, there were other elements to Abelson's attack (see Table 1). Blodget did not just ignore these issues nor did he go on the defensive. Instead, Blodget masterfully tackled these issues that were concerns from one perspective and applied his framework to show how and why these very concerns should be cause for celebration from a different perspective. He used the force of the opposition against itself, a kind of judo re-interpretation.

\section{Third episode: Suria vs. Blodget}

While our previous episode showed Blodget's triumph over his rivals, the following incident led to his ultimate downfall. Fast forward twelve months to the spring of the year 2000 . On April of that year, the NASDAQ fell by an abrupt 25.3 percent in one week. The "New Economy" suddenly became the dot-com crash; initial public offerings were suspended or delayed and business plans had to be re-fashioned. In this bearish context, a little-known bond analyst defied Blodget's dominance of the discourse on Amazon. The newcomer to the debate was Ravi Suria, a convertible bond analyst at Lehman Brothers. On June 23, 2000, Suria issued a dry, pessimistic report on Amazon that raised worries about an impeding credit squeeze. The 
report, which was lauded by premier business weekly Barron's as "refreshingly blunt..., free of the gibberish and webbygook that ooze form virtually all the brokerage stuff churned out on anything tech and everything Internet."

Suria's attack on Amazon involved a sequence that should by now be familiar to the reader: first discredit the existing frame, then propose a new one. Suria first attacked Blodget's categorization of Amazon as an Internet company. Comparing operating figures as "inventory turns" and "gross margins," he concluded that Amazon "is displaying the operational and cash flow characteristics of a normal retailer." The result, he argued, was that Amazon's challenges resembled those of bricks-and-mortar retailers: too much inventory, razor-thin margins and expensive returns.

Having rejected the dimensions of merit proposed by Blodget, Suria went on to propose his own. Suria was a convertible debt analyst. Debt analysts, like Suria, issue reports for creditors and look at companies with a different lens. Creditors fare very differently from regular stockholders in their exposure to the companies that they invest in. They face a large downside risk if the firm does not perform financially as their bonds will not be repaid; and very limited upside potential if it performs well, for as long as the firm can repay the bonds, the residual claims by creditors does not grow larger. In other words, creditors are different from shareholders in that the immediate downside of the company can become more important to them. As a result, debt analysts such as Suria also care more than equity analysts about the potential downside of the firms that they cover (see Kahneman \& Tversky, 1979).

Looking at Amazon as a retailer and valuing it as a bond Suria saw it in impending danger of a liquidity crisis. Suria warned Amazon bondholders about "a creditor squeeze" in the second half of the year 2000, caused by vendors worried that the firm would not pay them. The reason, he wrote, was that,

Current liabilities ... have grown much faster than current assets, clearly leaving Amazon with a much-depleted liquidity position as it enters the New Year.

If that squeeze were to happen, Suria wrote, it could lead to a painful restructuring of the company and spell doom for stockholders in Amazon. Following the report, Amazon's stock sank by $20 \%$. 
Blodget did his best to dismiss the issue, but the stock price fell, not to recover in the immediate future. In his report dated June 29, 2000, Blodget tried to counter the issues driving Suria's analysis (Table 3). Drawing from the most powerful of his metaphorical skills, Blodget established a parallelism between Amazon in the year 2000 and America Online in 1996, a firm that overcame temporary financial constraints to come back triumphant, yielding extraordinary returns to its shareholders. Blodget wrote,

AOL worked its way through [its] "gawky adolescent" period and is now the most powerful Internet company in the world. From a split adjusted low of $\$ 1.50$ in the midst of the crisis in late 1996, its stock has risen $33 \mathrm{X}$, or more than $3000 \%$. We believe Amazon shares many of the characteristics that made AOL worth the risk (Blodget and Good, 2000: 1)

Blodget thus strived to redirect the focus of the debate to Amazon's upside, as opposed to the Suria's downside.

This time, however, investors chose to ignore Blodget's arguments. The price of Amazon never recovered. For the following two years, it languished from a low $\$ 30$ s to an even lower $\$ 15$ in 2002 (see Fig. 1). Blodget's prominence turned against him, and the retail investors that lost money betting on Amazon and other dot-com stocks sued Blodget's bank, Merrill Lynch, for issuing "tainted" buy recommendations.

What led investors to believe Blodget in December 1998 and reverse course two years later? We propose that Blodget's framework had lost its credibility. Blodget had predicted that improvement of non-financial metrics such as number of customers or total sales increase would eventually translate into higher profits. This did not happen nor did it appear likely to transpire in the near future given Suria's pronouncements. Amazon had losses again in 1999 and in the year 2000. So did the rest of e-commerce companies. The sharp fall in the NASDAQ index of April 2000 signaled Amazon investors that it was probably time to switch frames.

This shows that the credibility of a frame is temporarily bound. Blodget issued frames with tests of verifiability built into them - predictions of what will happen when. Such timed predictions offered a shield of credibility against negative information for the duration of the period, but became explosive when time ran out. By July 2000, Amazon had reached a 
staggering volume of sales and had not yet come as close to profits as Blodget had predicted. Investors switched their allegiance to the view of Lehman's Suria.

In this regard, Suria may even have contributed to cutting short the time frame built into Blodget's framework laid out in 1998. Especially under conditions of Knightian uncertainty, bond traders may look for financial weaknesses in the short term to see if a company has enough cash to pay off its debts. In contrast, equity analysts may look at upside growth potential in the long term. Blodget tried to evoke time once again by suggesting "we believe that the current weakness provides a particularly good entry opportunity for long-term investors." In contrast, Suria focused on the short term stating "In its current situation of high debt load, high interest costs, spiraling inventory and rising expansion costs, we believe that current cash balances will last the company through the first quarter of 2001 under the best-case scenario.” In effect, Suria not only denied Blodget any possibility of buying additional time, but also may have contributed in the reduction of what little time that may have been left in Blodget's original framework.

The episode illustrates an additional point. It shows that different frames proposed by analysts do not immediately converge, as theory of rational decision-making or as a cascades theory would predict. Indeed, even as Suria was issuing his controversial analysis, Holly Becker the analyst covering Amazon.com for Lehman had a "buy" on the company at the time, only offering her own "downgrade" on Amazon a month later. In the meantime, two years after the initial controversy with Cohen in 1998, Blodget still rated Amazon a buy, while Suria rated it a sell.

\section{DISCUSSION}

An application of our perspective of analysts as frame makers to study Blodget's coverage of Amazon.com offered several insights. First, star analysts may rise up the status ladder by developing an original calculative frame, not merely by calculating worth using existing approaches or by following the crowd. Second, analysts employ new metrics, milestones and analogies to develop their original calculative frames. Third, controversy is bound to emerge as others too use their frameworks to arrive at non-convergent interpretations of emergent data. Fourth, analysts do not necessarily change their recommendation when confronted with these controversies. Instead, as Blodget demonstrated, they may redefine the issues using their 
frameworks. Fifth, an ability to redefine issues with a framework is dependent upon whether the clock built into an analyst's frame has any time left.

\section{Genesis of original calculative frames}

In informing us about calculation and isomorphism, the two major pe rspectives on analysts are silent about the origins of new calculative frames. Questions about the origins of novel calculative frames become all the more important when Knightian uncertainty surrounds early stages of firm emergence. During such periods, it is not clear what analysts should do when an approach for calculations has not yet stabilized. The problem is all the more vexing as there are very few to follow.

So, what should analysts do? The early history of analysts covering Amazon.com sheds some light. Blodget was a relatively new analyst at CIBC Oppenheimer. When he began his coverage of Amazon.com, a handful of other analysts such as Merrill Lynch's Jonathan Cohen had already begun covering Amazon.com. Cohen's framework relied heavily upon concepts borrowed from the "old economy." From this perspective, the valuation of Amazon.com, a firm at the forefronts of the emerging new economy, made no sense.

Blodget, in contrast, developed a new framework to understand the emergence of a whole new category of firms based on dynamics rooted in the "new economy." Blodget certainly did not conform to the bearish assessment that Cohen had offered. Instead, he offered a whole new way to calculate the worth of a firm whose market valuation defied old economy calculations.

A comparison of the recommendations that Blodget and Cohen (Table 1) had to offer confirms what Denzau and North (1994) argued. They suggested that under conditions of Knightian uncertainty, two individuals with different learning experiences might arrive at totally different conclusions. Indeed, at early stages of coverage, as in the case of early stages of technological emergence, there is a contest as to whose frame will prevail. And, in this case, it was Blodget's.

In this regard, we are reminded of Kuhn's articulation of paradigms. Kuhn ([1962] 1970:23) pointed out that "paradigms gain their status because they are more successful than their competitors in solving a few problems that the group of practitioners has come to recognize 
as acute." In the context of Amazon.com, old economy business models could not explain Amazon's valuation. At the same time, fund managers were reluctant to proclaim that they were simply following the herd - there was no bases for behaving like a day trader buying and selling on momentum. Yet fund managers were under enormous pressures to show performance. And it is here that the articulation of a new paradigm by Blodget appears have offered an answer that became the bases for making sense of the unfolding phenomenon. And once articulated, Blodget's framework endured till such time that "anomalies" built up.

These observations also help qualify our understanding of mimetic isomorphism (DiMaggio and Powell, 1983) especially as it pertains to analyses of emergent phenomena. A significant body of literature has explored the virtues of following the crowd (Bickchandani et al., 1992; Rao et al. 2001; Abrahamson, 1991). Only now have some begun to look at the benefits of non-conformance (Fiol, O'Connor and Aguinis, 2001; Garud \& Karnoe, 2001). In striking out from Cohen with a framework that could better represent Amazon.com as a company of the new economy, Blodget generated enormous status for himself. Eventually, Blodget become the number one ranked analyst on the Street, according to Institutional Investor.

A related question has to do with the emergence of novel sense making mechanisms in general such as new industry categories. We note that Blodget valued Amazon by assuming for it the same parameter for gross margin as a direct-sales company like Dell, but estimated for it the sales growth rate of a start-up company, which Dell was not at the time. Take together, these two characteristics (high-margin, high-growth) formed the basis for a distinct new category, the Internet company. Thus, the Amazon case suggests that new categories and frameworks arise from recombination of existing networks. This contrasts with Zuckerman's model of categorical stasis. His model posits that analysts calculate by comparison within alternatives. In contrast, the unparalleled breadth and complexity of analysts' frameworks (relative to other critics) allows analysts to create new categories by mixing and matching from existing ones.

\section{Analysts as frame makers, not predictors}

How should we understand and evaluate analysts' reports during periods of Knightian uncertainty? Many look for accuracy of predictions. If we were to adopt a perspective on analysts as rational calculating agents, "inaccuracies" in forecasts are ascribed to analysts' errors. 
Such regret is to be found if we were to adopt the information cascades perspective as well. According to this perspective, analysts express post-decision regret even though they follow the crowd in real time (Rao et al., 2001).

A perspective on analys ts as frame-makers offers a different set of insights. Analysts create frameworks to make sense of emergent phenomenon during early stages of firm and industry emergence when there is no stable set of information. These frameworks serve as templates to make sense of emerging data at any given point in time. At the same time, they serve as templates that evoke future possibilities about companies such as Amzon.com. As Hogarth (1987:101) pointed out, "The assessment of uncertainty in conditions of ambiguity therefore involves a compromise between 'what is' (i.e. the anchor which could be data based) and 'what might or could be' (i.e. the product of imagination). Consequently, it does not make sense to talk about accuracy and post-decision regret.

So, how does one put together an original calculative frame? Callon has suggested that calculation is an outcome of a process of associations. When we say that a product is worth ' $\mathrm{X}$ ', we implicitly acknowledge that the product belongs to a certain category and that specific evaluation metrics ought to apply. It is in a similar way that Blodget established a network of associations for Amazon.com within his calculative frame. For instance, he offered new metaphors such as Amazon as a portal rather than as a bookstore to establish the future potential of the company. He also offered milestones that Amazon.com would have to meet in order for his valuation prophecy to come true. These events could only transpire in the future whereas investments had to be made in the present. Consequently, Blodget proposed new metrics for evaluation such as clicks and eyeballs as proxies with which to calculate the worth of Amazon.com.

In a recent paper Czarniawska (2001) offer a new concept -- logic of representation - that is useful to understand what Blodget was able to accomplish in generating his calculative frame. Czarniawska pointed out that logic of representation "follows the axioms of formal rationality. It employs ostensive definitions and it aims at discovering mechanical connections between attributes, as in contingency theory. In that way, it resembles the logic of theory, but it differs 
from the latter in that it is rhetorically accomplished and ... uses its narrative knowledge with gusto."

Blodget's early reports provide valuable lessons in the art of representation. He employed theory in a way so as to surface new possibilities. Having compared Amazon to a portal, he then proceeded to offer fund managers an opportunity based on an upside potential for Amazon.com. Do the math he said, and Voila! We have a value of $\$ 10$ b. for Amazon.com. In support of this argument, he packed his report with data, calculations and charts (almost $40 \%$ of his 31 page report). Given that there existed only "partial knowledge" (Knight, 1921) of Amazon during early stages of its emergence, such data, calculations and charts could only have served as "symbols of competence" (Feldman \& March, 1981: 178).

Blodget's representation skills were also evident in his ability to offer fund managers a bridge between the past, present and future. His skills were most evident in his ability to covert a potential threat - the fundamental uncertainty that surrounded the emergence of Amazon.com in particular and the Internet industry in general - into an opportunity for fund-managers. Fundamental uncertainty can be threatening to those who have short time horizons. Under these conditions, one is likely to adopt a conservative "mini-max" criterion for making a choice (Luce \& Raiffa, 1957). However, by mobilizing time as a resource, Blodget was able to suggest that it was precisely Knightian uncertainty that offered those who were not faint of heart the investment opportunities that they craved.

The academic literature has offered a lot of insights about formworks (cf. Goffman, 1974). However, the incorporation of time into a frame has received little or no attention. In this regard, Blodget's report serves to highlight the utility of time that is built into an analyst's calculative frame. The time that is built in serves as a focal point for all interested parties. Additionally, it provides analysts and fund managers with an opportunity to convert abstract concepts into concrete numbers and Knightian uncertainty into investment possibilities. But, most importantly, it establishes a period of legitimacy for the framework and its internal logic.

In sum, Blodget's reports shows that calculative frames are networks of associations among parameters and independent variables that establish relationships of equivalence between some known magnitudes and the value of securities (Callon, 1988). This network is based on 
prexisting cognitive schemas, in particular, on industry categories. In addition, it also includes some scope conditions, most notably a time-frame of applicability.

\section{Divergent not convergent assessments among stakeholders}

Both the information processing and the information cascades perspectives on analysts predict convergent assessments, although for different reasons. The information processing perspective suggests that all analysts must come to the same conclusion given efficient markets. The information cascades perspective comes to the same conclusion as analysts mimic each other.

Our framework approach suggests that there is a possibility for interpretations to diverge. After all, frameworks dictate how one interprets emergent data. And, to the extent that different frameworks are built upon different metaphors, metrics and milestones, it is very likely that different interpretations will emerge. As Denzau and North (1994:3-4) pointed out, "Under conditions of uncertainty,...individuals with different learning experiences (both cultural and environmental) will have different theories (models, ideologies) to interpret that environment. Moreover the information feedback from their choices is not sufficient to lead to convergence of competing interpretations of reality."

It is therefore not surprising to note that Barron's report interpreted emerging data in a manner that contradicted the interpretations that Blodget had arrived at. For instance, Barron's report lamented that Amazon was continuing to make a loss. Blodget replied by suggesting that these so called losses were in reality investments. Barron's report suggested that WarMart would wipe out Amazon. Blodget seized upon this opportunity to compare Amazon.com with Wal-Mart and to suggest that Wal-Mart's valuation should be a basis for valuing Amazon as well.

\section{Path dependence and persistence rather than updating and following}

Perspectives on analysts as calculators and as followers suggest that analysts will update their forecasts as new information becomes available or as they follow others. The perspective on analysts as frame makers provides a counter view. Specifically, it is possible that analysts and fund managers may stick to a frame even when confronted with data that appears to contradict the conclusions that they had reached. 
When attacked by Barron's for instance, Blodget neither updated nor reversed his course of action to follow some other analyst. Ins tead, Blodget was successful in using the very data generated by Barron's in its attack of Amazon to strengthen his own position. And, he did so by using his framework to reinterpret the data used by Barron's - he turned iron into gold.

Clearly, this was skilled performance. Going beyond skill, however, the incident reveals a lot about how frames work. First, analysts and other fund managers become accustomed to a specific framework with its associated calculation apparatus. Sunk costs, learning effects, coordination processes as well as shared images of the future serve to hold a frame in place for certain duration of time (Arthur, 1985). Consequently, path dependence (David, 1985) rather than random walks (Malkiel, 1973) describe analysts as frame-makers.

Second, the frames that analysts establish become intertwined with their credibility. These frameworks are public faces of analysts and they signal commitment (Frank, 1988). An analyst who frames a stock differently every month - proclaiming it to be a bookseller in January, an Internet company in February and an e-commerce portal in March - would end up diminishing his own credibility.

In our own research, we have found that entrepreneurs create a "deviation step" (Garud \& Karnoe, 2001) - a bracketing of time with a frame - that allows entrepreneurs to deal with the paradoxes of emergence. These paradoxes arise from contradictory pressures that arise from a need to learn as opposed to a need to persist. On the one hand, entrepreneurs have to open themselves to feedback. On the other, they have to close themselves from feedback in order to persist. Deviation steps allow entrepreneurs to make important strides with their initiative before they expose their ideas to the harsh market selection criteria.

In a similar way, Blodget's frame had a deviation step built into it. Blodget had mobilized time - a period of five years in his original frame. As a result, his calculative frame possessed legitimacy for the five-year period. Consequently, Blodget could reinterpret Barron's data to his advantage.

These observations provide the advantages of viewing analysts as frame makers. Existing perspectives on analysts can neither explain the emergence of controversies nor the value of persistence. As our analysis of Blodget's coverage of Amazon shows, however, these dynamics 
are a part of valuation. Moreover, the perspective on analysts as frame makers provides a counter to the criticism against analysts for not changing their "buy" recommendations on some stocks even as their price lost $90 \%$ of its value. Specifically, it is possible that analysts and fund managers might stick to a frame even when confronted with data that appears to contradict the conclusions that they had reached.

\section{Punctuated equilibrium, not irrational exuberance and pessimism}

If frames have powers to act as shields, do they last forever? What explains the fact that Suria was successful in destroying Blodget's framework? Denzau and North (1994) provide a fascinating proposition in this regard. They suggested that frames (mental models and institutions in their terms) serve several purposes - one is to shape internal mental models, and the second is to shape external institutional structures. To the extent that there is a mismatch between the time clock built into a frame and the time that it takes for institutional structures to emerge, there arises an asynchrony that eventually exacts a legitimacy toll on the individuals who have proposed a specific calculative frame.

To develop this proposition, Denzau and North (1994) consider the asynchronies that might emerge between the path dependence associated with individual's frames (the time clock in our words) and the dynamics of emergence of the institutions that the frameworks model. Such an asynchrony, Denzau and North (1994) pointed out, results in the creation of a punctuated equilibrium process in markets in the making (Eldredge \& Gould, 1972). As Denzau and North stated, "Punctuated equilibrium involves long periods of slow, gradual change punctuated by relatively short periods of dramatic changes, which we can presume to be periods of representational redescription."

In other words, to the extent that analyst's prophecies are not fulfilled in a timely fashion, their frames loose legitimacy and become vulnerable to attacks. This is what happened when Suria attacked Amazon and Blodget. The clock built into Blodget's frame simply ran out of time. It was not that Blodget's original calculative framework was "wrong" about Amazon and its potentials. After all, Amazon still exists is showing modest profits, and is trading around $\$ 50 \mathrm{a}$ share, up almost $500 \%$ from its low of $\$ 10$ in 2002. If Blodget was "wrong" then, it was in the sense that the estimation of the time frame within his enacted frame - an image of the future in 
Knight's terms - turned out to be inconsistent with the temporal rhythms of Amazon.com's emergence.

The crumbling of Blodget's frame, along with the collapse of the Internet bubble, seriously discredited the carefully laid out elements of Blodget's and other new economy analysts' frames. Suria, exploited these vulnerabilities. A convertible bond trader, Suria used the legitimacy that he has garnered from his earlier transactions to devastating effect. And, in the process, Suria raised his own status in his community.

In sum, our framework perspective offers a more nuanced understanding of bubbles and bursts (Abolafia \& Kilduff, 1988). Rather than view bubbles and bursts as outcomes of irrational exuberance and pessimism (attributions that can be inferred from a view of analysts as calculators or as lemmings), our perspective suggests that bubbles and bursts are a part and parcel of emergence. As new technologies, markets, social arrangements unfold, a framing process unfolds. Proxies and analogies contained within frames create temporary markets that are held together by a network of association for a certain period of time. Successful framing efforts will attract resources in different forms that will fuel the bubble. Over time, as temporal mismatches emerge between the time frame within a framework and the temporally pattern of emergence, the bubble will collapse.

\section{CONCLUSION}

We began the paper by introducing two perspectives on analysts from the literature. One views analysts as rational calculators, continually updating their forecasts as new information becomes available. A second views analysts as lemmings that simply follow one another. Neither perspective, we argued, can fully explain the value that fund mangers seem to derive from analysts' reports. Specifically, fund managers' ranking criteria, as reported by Institutional Investor magazine, suggests that analysts are valued for their ability to provide industry specific and firm specific knowledge. And, such knowledge, we suggested, cannot be generated without a framework.

Our discussion provides fresh meaning to the term analysis, especially under conditions of Knightian uncertainty. Analysts do not merely calculate, nor do they just follow the crowd. Through their analysis, securities analysts provide a road map, a representation scheme, of a 
phenomenon that is inherently fuzzy and emergent. A market without frame-makers would continue valuing new companies as existing ones, thereby hampering innovation, adaptation and economic growth. By offering intermediate metrics, the appropriate network of connections and temporary comparisons, analysts' frames facilitate transactions, especially when there is no certainty out there.

These points reinforce the need to add frame-making as an important perspective for studying the roles of analysts along with the prevalent perspectives that views them as information processors or as followers. Such a perspective opens up many lines of inquiry that we have not addressed in this paper. For instance, is $\mathfrak{\mathrm { t }}$ possible for mimetic differentiation to unfold in the creation and use of analytical tools and reports by analysts? Specifically, what portions of a report might we find to be similar and what portions different when we probe deeper into the reports of a cohort of analysts over time? How do analysts overcome path dependencies as they follow volatile securities over time? Under what conditions and to what extent do Analysts' frameworks mediate fund manager's expectations. We believe that a frameworks perspective opens up many such exciting lines of inquiry. 


\section{REFERENCES}

Abelson, A 1999. "Up and Down Wall Street: The answer to everything," Barron's, May 3: 5-6. Abrahamson, E. 1991. "Managerial fad and fashion: the diffusion and rejection of innovations". Academy of Management Review. 16(3):586-612.

Abolafia, M. Y. and Martin K. 1988. "Enacting Market Crisis: The Social Construction of a Speculative Bubble," Administrative Science Quarterly, Vol. 33(2): 177-193.

Aldrich, H.E. \& Fiol, C.M. 1994. Fools rush in? The institutional context of industry creation. Academy of Management Review, 19: 645-670.

Allison, G. T. 1971. Essence of Decision: Explaining the Cuban Missile Crisis. Boston: Little Brown and Co.

Arthur, B. 1988: Self-reinforcing mechanisms in economics. In P. Anderson, et al. (eds.) The Economy as an Evolving Complex System. Reading, MA: Addison-Wesley.

Arthur, B. 1999. "The End of Certainty," pp. 31-47 in John Clippinger, ed. The Biology of Business : Decoding the Natural Laws of Enterprise. Jossey-Bass: San Francisco.

Barley, S. 1986: Technology as an occasion for restructuring: Evidence from the observations of CT scanners and the social order of radiology departments. Administrative Science Quarterly, 31, 78-108.

Bateson, G. (1972). Steps to an ecology of mind. San Francisco, CA: Chandler Publishing Co.

Brandenburger, A.. 2002. "The Power of Paradox: Some Recent Developments in Interactive Epistemology." Manuscript, Stern School of Business.

Berger, P. and Luckmann, T. 1967, The Social Construction of Reality. London: Penguin.

Beunza, D and Stark, D. 2004 "Tools of the Trade: The Socio-Technology of Arbitrage in a Wall Street." Industrial and Corporate Change forthcoming.

Bikhchandani, S, Hirshleifer, D. and Welch, I. 1992. "A theory of fads, fashion, custom, and cultural change as informational cascades," Journal of Political Economy, 100( 5): $992-$ 1026.

Bidwell C. M. III. 1977. "How Good is Institutional Brokerage Research?” Journal of Portfolio Management 26-31.

Blodget, H. M. and Erdmann, N. 1998. "Amazon.com. Initiating with Buy; Analyzing Competition, Profitability and Valuation." Equity Research report, CIBC Oppenheimer, October 13.

and Elizabeth Anning, 1998b. “Amazon.com. Raising Price Target to \$400." Equity Research report, CIBC Oppenhe imer, December 16th. 1999. “Amazon.Bomb?" Equity Research report, Merrill Lynch, June 1.

and Daniel Good. 2000. "Is AMZN now AOL in 1996," Equity Research Report, Merrill Lynch. June 29.

Bowker, G. C. and Star, S. L. 2000: Sorting Things Out: Classification and its Consequences. Cambridge, MA: The MIT Press.

Callon, M. 1998. "Introduction: the embeddedness of economic markets in economics." In The Laws of the Markets edited by Michel Callon. Oxford: Blackwell Publishers.

Cochoy, F. 1998. "The Contribution of Social Sciences to the Construction of Markets: The Case of Marketing," in Michel Callon, ed., The Laws of the Markets. Oxford: Blackwell Publishers.

Cowles, A. 1933. "Can Stock Market Forecasters Forecast?", 1933, Econometrica 1, 309-325.

Czarniawska B. 2001. "Is it possible to be a constructionist consultant?" Management Learning, 32(2):253-266. 
David, P. 1985. "Clio and the economics of QWERTY." Economic History, 75: 227-332.

Denzau, A. T. and North, D. 1994. "Shared Mental Models: Ideologies and Institutions," Kyklos, Vol. 47 (1): 3-31.

Diefenback, R. 1972. "How Good is Institutional Brokerage Research?" Financial Analysts Journal, 29: 54-60.

DiMaggio, P. and Powell. W. 1983. "The Iron Cage Revisited: Institutional Isomorphism and Collective Rationality in Organizational Fields." American Sociological Review, 48: 147160.

Dosi, G. 1982.'Technological paradigms and technological trajectories." Research Policy 11: $147-162$.

Eldredge, N., and Gould S.J., "Punctuated equilibria: an alternative to phyletic gradualism," in T.J.M. Schopf (ed.), Models in Paleobiology, San Francisco: Freeman, Cooper and Co., 1972, 82-115.

Fama, E. F. 1969. "Efficient Capital Markets: A Review of Theory and Empirical Work." Journal of Finance, 49: 283-306.

Feldman, M. and March. J. G. 1981. "Information in organization as signal and symbol." Administrative Science Quarterly 26:171-186.

Fiol, C. M., Edward J. O Connor and Herman Aguinis. 2001. "All for One and One for All? The Development and Transfer of Power Across Organizational Levels." Academy of Management Review 26:224-242.

Frank, R. H. 1988. Passions within reason: the strategic role of the emotions, New York : Norton.

Gallison, P. 1997. Image and Logic: A Material Culture of Microphysics. Chicago: University of Chicago Press.

Garud, R. and Karnøe. P. 2001. "Path Creation as a Process of Mindful Deviation," in Garud and Karnøe, eds., Path Dependence and Creation. Mahwah, NJ: Lawrence Erlbaum Associates.

Garud, R. and Rappa, M. 1994. "A socio-cognitive model of technology evolution" Organization Science, Vol. 5, No. 3, pp. 344-362.

Goffman, E. 1974. Frame analysis: An essay on the organization of experience. New York: Harper \& Row.

Gogoi, P and Zuckerman, G. 1999. "In Wake of Amazon.com's Convertible-Note Sale, Debt Outlook for Other Internet Firms Is Unclear," Wall Street Journal, February 1: C19.

Granovetter, M. S. 1985. "Economic action and social structure: The problem of embeddedness," American Journal of Sociology 19 (3): 481-510.

Hagglund, P. B. 2000. "Sense-making Into Stable Quasi-Companies," Academy of Management Proceedings, Managerial and Organizational Cognition Division.

Hogarth, R. 1980. Judgment and Choice. New York: John Wiley.

Huff, A. S. 1990. Mapping Strategic Thought. Chicester, UK: John Wiley \& Sons Ltd.

Institutional Investor. 1999. "The 1999 All-America Research Team." October: 107-211.

Kahneman, D. and Tversky. A. 1979. "Prospect Theory: An Analysis of Decision under Risk." Econometrica 46 (2): 171-185

Kelly, G. A. 1963. A theory of personality: The psychology of personal constructs. New York: W. W. Norton.

Knight, F. 1971. Risk, Uncertainty and Profit. Chicago, University of Chicago Press. 
Knorr Cetina, K. D. and Bruegger, U. 2002. "Global Microstructures: The Virtual Societies of Financial Markets", American Journal of Sociology 107(4):

905-50 Kuhn, T. S., 1970. The Structure of Scientific Revolutions, Chicago: Univ. of Chicago Press, 2nd ed.

Lant, T. K., \& Baum, J. A.C. 1995."Cognitive Sources of Socially Constructed Competitive Groups: Examples from the Manhattan Hotel Industry," In W.R. Scott \& S. Christensen, (Eds.), The Institutional Construction of Organization: International and Longitudinal Studies, pp. 15-38. .Newbury Park, CA: Sage Publications.

Latour, B. 1987. Science in Action: How to follow scientists and engineers through society. Cambridge, Mass.: Harvard University Press.

Logue, D. E., and D. L. Tuttle. 1973. "Brokerage House Investment Advice." Financial Review 8: $38-54$.

Luce, R.D. \& H. Raiffa (1957), "Games and Decisions." Wiley, New York.

MacKenzie D. and Y. Millo. 2003 "Constructing a Market, Performing Theory: The Historical Sociology of a Financial Derivatives Exchange." American Journal of Sociology 108.

Malkiel, B. G. 1973. A random walk down Wall Street. New York: Norton.

McNichols M. and O'Brien, P. 1997. "Self-Selection and Analyst Coverage." Journal of Accounting Research, v. 35(SS), pp. 167-199

Nelkin, D. 1979. (ed.) Controversy, politics of technical decisions. Beverly Hills, CA: Sage Publications.

Phillips, D. J., and Zuckerman, E.W. 2001. "Middle-status conformity: Theoretical restatement and empirical demonstration in two markets." American Journal of Sociology 107:379420.

Podolny, J.M. 1993. "A Status-Based Model of Market Competition," American Journal of Sociology 98(4): 829-72.

Porac, J. F., Thomas, H., Wilson, F., Paton, D, and Kanfer, A. .1995. "Rivalry and the Industry Model of Scottish Knitwear Producers." Administrative Science Quarterly. 40: 203-227.

Radner, R. 1997. "Bounded Rationality, Indeter minacy, and the Managerial Theory of the Firm," in Z. Shapira, ed., Organizational Decision Making, Cambridge U. Press, Cambridge, 1997.

Rao, H. Greve H. and Davis. G. 2001. "Fool's gold: Social proof in the initatiation and abandonment of coverage by Wall Street Analysts," Administrative Science Quarterly, 46, 502-526.

Samuelson, P. (1965) "Proof that Properly Anticipated Prices Fluctuate Randomly." Industrial Management Review. 6, 41-49 .

Savage, L. J. 1954. The Foundations of Statistics. Wiley: New York.

Shiller, R. J. 2000. Irrational Exuberance. Princeton, NJ: Princeton University Press.

Stark, D. 2000. "For a Sociology of Worth." Keynote address, Annual Conference of the European Association of Evolutionary Political Economy, Berlin, November 3.

Tushman, M.L., \& Anderson, P. 1986. Technological discontinuities and organizational environments. Administrative Science Quarterly, 31: 439-465.

Weick, K. E. 1979. The social psychology of organizing (2nd ed.). Reading, MA: AddisonWesley.

Zuckerman, E. W. 1999. "The Categorical Imperative: Securities Analysts and the Illegitimacy of Discount." American Journal of Sociology 104:1398-1438. 
Figure 1. Three Critical Incidents in the Coverage of Amazon.com by Henry Blodget, Merrill Lynch

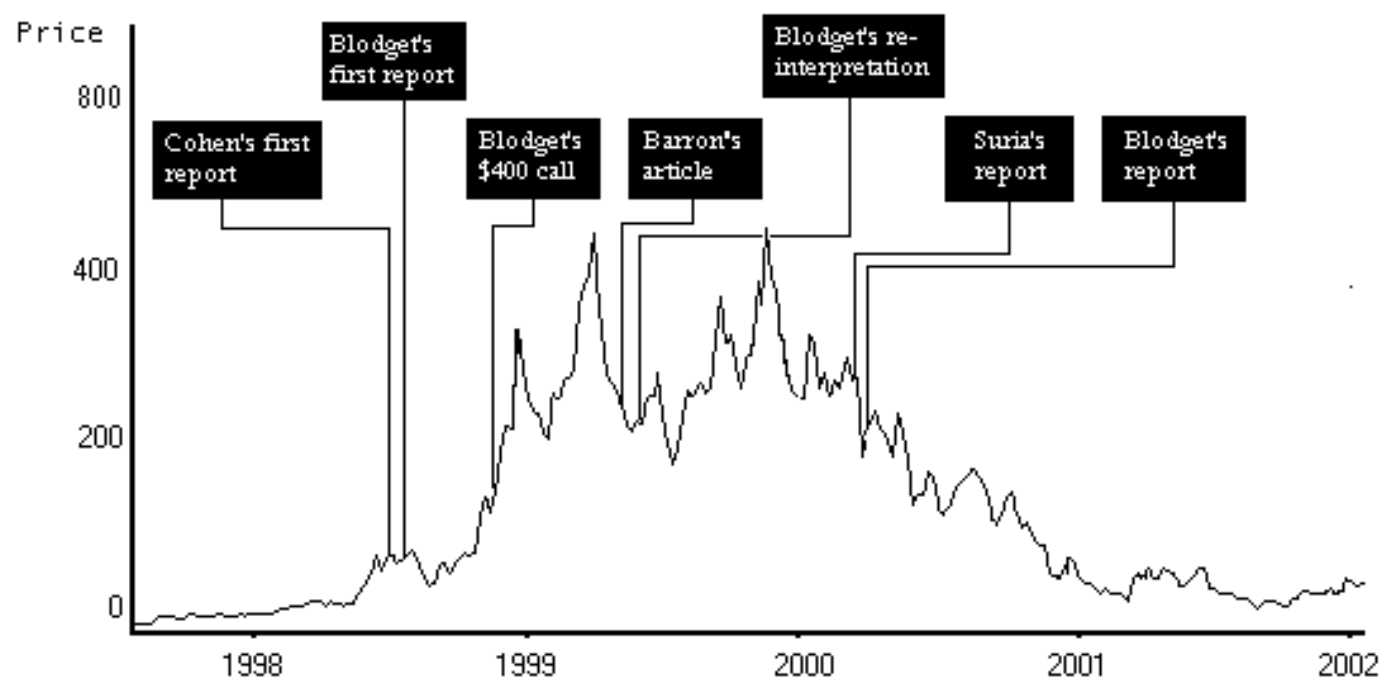


Table 1: Institutional Investors' rank of desirable analyst attributes by U.S. equity assets under management. Source: $\underline{\text { ww.ii.com }}$

\begin{tabular}{clcccccc}
\hline $\begin{array}{c}\text { Overall } \\
\text { Rank }\end{array}$ & Attributes & $\begin{array}{c}\$ 75 \mathrm{~b} . \\
\text { or More }\end{array}$ & $\begin{array}{c}\$ 30 \mathrm{~b} . \\
\text { to } \$ 74.9 \mathrm{~b} .\end{array}$ & $\begin{array}{c}\$ 10 \mathrm{~b} . \\
\text { to } \$ 29 \mathrm{~b} .\end{array}$ & $\begin{array}{c}\$ 5 \mathrm{~b} . \\
\text { to } \$ 9.9 \mathrm{~b} .\end{array}$ & $\begin{array}{c}\$ 1 \mathrm{~b} . \\
\text { to } \$ 4.9 \mathrm{~b} .\end{array}$ & $\begin{array}{c}\text { Less than } \\
\$ 1 \text { billion }\end{array}$ \\
\hline 1 & Industry knowledge & 1 & 1 & 1 & 1 & 1 & 1 \\
2 & Written reports & 3 & 2 & 3 & 3 & 3 & 2 \\
3 & Special services $*$ & 2 & 3 & 2 & 5 & 5 & 5 \\
4 & Servicing & 4 & 2 & 4 & 2 & 6 & 6 \\
5 & Stock selection & 6 & 5 & 5 & 4 & 2 & 3 \\
6 & Earnings estimates & 5 & 6 & 6 & 6 & 4 & 4 \\
7 & Quality of sales force & 7 & 7 & 7 & 7 & 7 & 7 \\
8 & Market making/ execution & 8 & 8 & 8 & 8 & 8 & 8 \\
\hline
\end{tabular}

* Company visits, conferences, etc.

Table 2: Institutional Investors' All-America Research Team, in the Internet, New Media and E-Commerce category, 1999-2000. Source: www.ii.com

\begin{tabular}{|c|c|c|c|c|}
\hline Rank & 1998 & 1999 & 2000 & 2001 \\
\hline First & $\begin{array}{l}\text { Mary Meeker } \\
\text { (Morgan Stanley) }\end{array}$ & $\begin{array}{l}\text { Mary Meeker } \\
\text { (Morgan Stanley) }\end{array}$ & $\begin{array}{l}\text { Henry Blodget } \\
\text { (Merrill Lynch) }\end{array}$ & $\begin{array}{l}\text { Holly Becker } \\
\text { (Lehman Brothers) }\end{array}$ \\
\hline Second & $\begin{array}{l}\text { Jamie Kiggen } \\
\text { (Donaldson, Lufkin \& J.) }\end{array}$ & $\begin{array}{l}\text { Jamie Kiggen } \\
\text { (Donaldson, Lufkin \& J.) }\end{array}$ & $\begin{array}{l}\text { Mary Meeker } \\
\text { (Morgan Stanley) }\end{array}$ & $\begin{array}{l}\text { Anthony Noto } \\
\text { (Goldman Sachs) }\end{array}$ \\
\hline Third & $\begin{array}{l}\text { Michael Parekh } \\
\text { (Goldman Sachs) }\end{array}$ & $\begin{array}{l}\text { Henry Blodget } \\
\text { (Merrill Lynch) }\end{array}$ & $\begin{array}{l}\text { Jamie Kiggen } \\
\text { (Donaldson, } \\
\text { Lufkin \& J.) }\end{array}$ & $\begin{array}{l}\text { Henry Blodget } \\
\text { (Merrill Lynch) }\end{array}$ \\
\hline $\begin{array}{l}\text { Runner- } \\
\text { up }\end{array}$ & $\begin{array}{l}\text { Keith Benjamin } \\
\text { (BancBoston Robertson } \\
\text { Stephens) }\end{array}$ & $\begin{array}{l}\text { Keith Benjamin } \\
\text { (BancBoston Robertson } \\
\text { Stephens) }\end{array}$ & & $\begin{array}{l}\text { Jamie Kiggen } \\
\text { (Credit Suisse First } \\
\text { Boston) }\end{array}$ \\
\hline $\begin{array}{l}\text { Runner- } \\
\text { up }\end{array}$ & $\begin{array}{l}\text { Alan Braverman } \\
\text { (Deutsche Bank } \\
\text { Securities) }\end{array}$ & $\begin{array}{l}\text { Michael Parekh } \\
\text { (Goldman Sachs) }\end{array}$ & & $\begin{array}{l}\text { Charles (Lanny) Baker } \\
\text { (Salomon Smith Barney) }\end{array}$ \\
\hline $\begin{array}{l}\text { Runner- } \\
\text { up }\end{array}$ & $\begin{array}{l}\text { Jonathan Cohen } \\
\text { (Merrill Lynch) }\end{array}$ & & & \\
\hline
\end{tabular}


Table 3: A Comparison of Blodget's Perspective on Amazon.com with those of Cohen's, Abelson's \& Suria's Blodget vs. Cohen, 1998

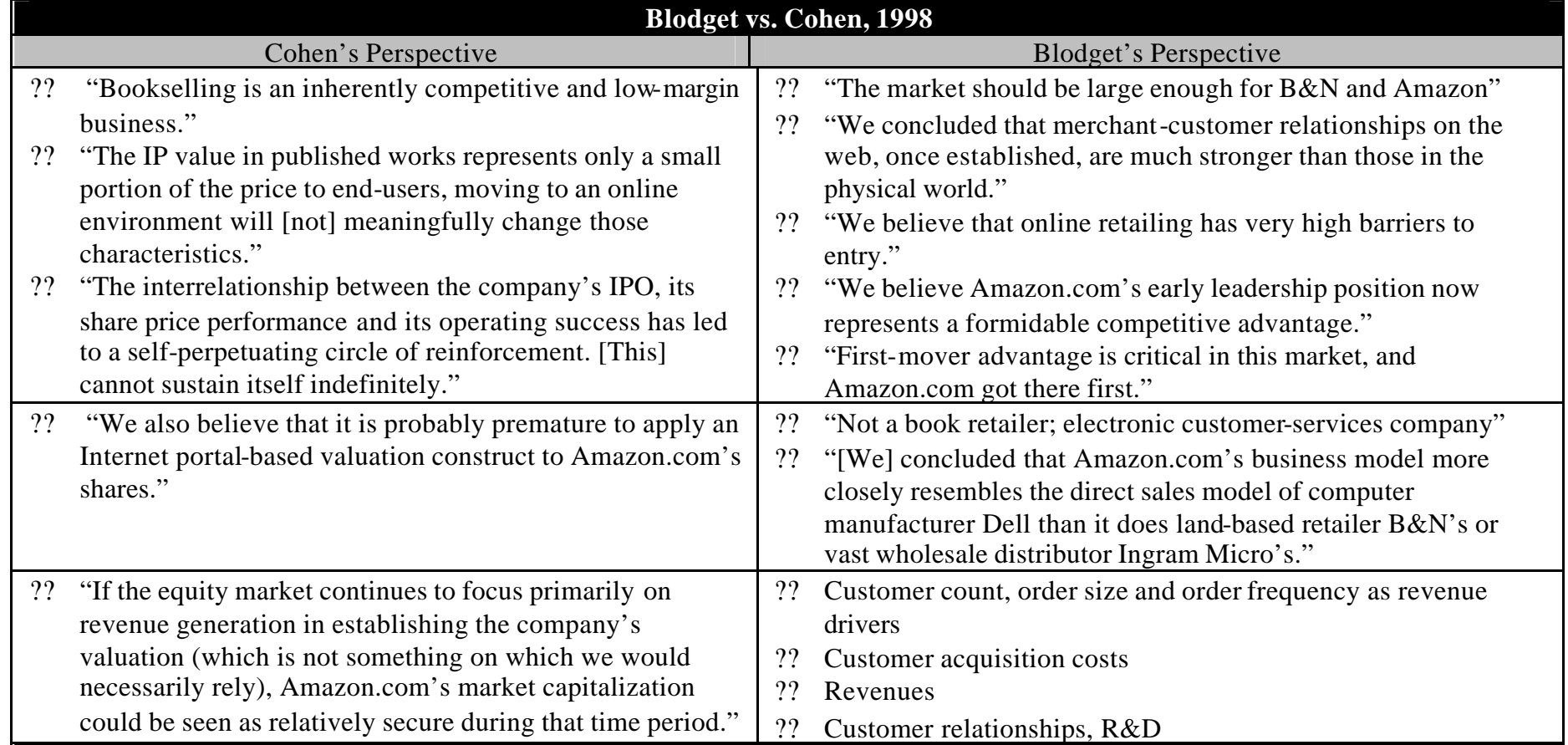

\begin{tabular}{|c|c|c|}
\hline \multicolumn{3}{|c|}{ Blodget vs. Abelson, 1999} \\
\hline & Abelson's Perspective & Blodget's Perspective \\
\hline$? ?$ & $\begin{array}{l}\text { "Amazon.com isn't profitable now-so it probably will } \\
\text { never be worth much of anything." }\end{array}$ & $\begin{array}{l}\text { ?? "As any smart investor understands, there is a big difference } \\
\text { between 'losing' money and 'investing' money... if } \\
\text { Amazon.com were to cut back on its investments in order to post } \\
\text { a near-term profit, we believe it would be worth considerably } \\
\text { less in three to five years." }\end{array}$ \\
\hline$? ?$ & $\begin{array}{l}\text { "Amazon.com is just another middleman, and increasing } \\
\text { competition from authors and publishers selling direct, } \\
\text { other booksellers, and Wal-Mart will soon render it less } \\
\text { attractive." }\end{array}$ & $\begin{array}{l}\text { ?? "Amazon.com is indeed a middleman, but in industries in which } \\
\text { middlemen are valuable-such as retailing - the best ones can be } \\
\text { worth a lot, even if they have skimpy margins (see Wal-Mart's } \\
\text { \$200B valuation)." }\end{array}$ \\
\hline$? ?$ & $\begin{array}{l}\text { "Amazon.com's 'pro forma' results (pre-merger-related } \\
\text { expenses) are irrelevant-what really matters are GAAP } \\
\text { net losses." }\end{array}$ & $\begin{array}{l}\text { ?? "This is not true, in our opinion. In this industry, as a result of } \\
\text { the subjectivity and randomness involved... we do not believe } \\
\text { that GAAP earnings offer a true picture of the power of } \\
\text { company's business. Instead, we believe that investors should } \\
\text { focus on operating earnings and return on invested capital." }\end{array}$ \\
\hline \multicolumn{3}{|c|}{ Blodget vs. Suria, 2000} \\
\hline & Suria's Perspective & Blodget's Perspective \\
\hline$? ?$ & $\begin{array}{l}\text { "From a bond perspective, we find the credit extremely } \\
\text { weak and deteriorating." }\end{array}$ & ?? "We remain comfortable with Amazon's cash position." \\
\hline$? ?$ & $\begin{array}{l}\text { "The company is displaying the operational and cash flow } \\
\text { characteristics of a normal retailer, despite its 'virtual' } \\
\text { pedigree." }\end{array}$ & $\begin{array}{l}\text { ?? "On a macro level, we find it interesting to note the many } \\
\text { similarities between Amazon today and AOL in } 1996 \text {-- long } \\
\text { before the latter company became the profitable, blue chip } \\
\text { Internet play it is today." }\end{array}$ \\
\hline ?? & $\begin{array}{l}\text { "We believe that that the combination of negative cash } \\
\text { flow, poor working capital management and high debt } \\
\text { load in a hyper-competitive environment will put the } \\
\text { company under extremely high risk" }\end{array}$ & $\begin{array}{l}\text { ?? "Although AMZN will likely remain volatile throughout the } \\
\text { summer, we believe that the current weakness provides a } \\
\text { particularly good entry opportunity for long-term investors." }\end{array}$ \\
\hline
\end{tabular}

